\title{
Multiple roles of Sonic Hedgehog in the developing human cortex are suggested by its widespread distribution
}

\author{
Fani Memi ${ }^{1,3} \cdot$ Nada Zecevic ${ }^{1}$ Nevena Radonjić ${ }^{2}$ \\ Received: 29 September 2017 / Accepted: 25 January 2018 / Published online: 28 February 2018 \\ (c) The Author(s) 2018. This article is an open access publication
}

\begin{abstract}
Sonic Hedgehog (Shh) plays an instrumental role in brain development, fine-tuning processes such as cell proliferation, patterning, and fate specification. Although, mutations in the $S H H$ pathway in humans are associated with various neurodevelopmental disorders, ranging from holoprosencephaly to schizophrenia, its expression pattern in the developing human brain is not well established. We now determined the previously not reported wide expression of $S H H$ in the human fetal cerebral cortex during most of the gestation period (10-40 gestational weeks). This spatiotemporal distribution puts Shh in a position to influence the fundamental processes involved in corticogenesis. SHH expression increased during development, shifting from progenitor cells in the proliferative zones to neurons, both glutamatergic and GABAergic, and astrocytes in upper cortical compartments. Importantly, the expression of its downstream effectors and complementary receptors revealed evolutionary differences in $\mathrm{SH} H$-pathway gene expression between humans and rodents.
\end{abstract}

Keywords Cerebral cortex $\cdot$ Human fetal brain $\cdot$ Morphogen $\cdot$ SHH receptors

\section{Introduction}

Corticogenesis is a developmental process that requires coordination of the signaling pathways providing mitogenic signals and guiding the regulation of symmetric/asymmetric divisions of neuronal progenitors, positional information, differentiation signals, and a balance of excitation and inhibition in the cortex. Cortical development has been extensively studied in mice, and although it is considered to be

Electronic supplementary material The online version of this article (https://doi.org/10.1007/s00429-018-1621-5) contains supplementary material, which is available to authorized users.

Fani Memi

fani.memi@ucl.ac.uk

Nevena Radonjić

radonjic@uchc.edu

1 Department of Neuroscience, University of Connecticut Health Center, Farmington, CT 06030, USA

2 Department of Psychiatry, University of Connecticut Health Center, 263 Farmington Avenue, Farmington, CT 06030, USA

3 Department of Cell and Developmental Biology, University College London, 21 University Street, London WC1E 6DE, UK generally well conserved in mammals, a number of changes and novelties have emerged during evolution that may underlie the biological basis for the higher cognitive and motor abilities that are specific to humans (Geschwind and Rakic 2013; Silbereis et al. 2016). Sonic Hedgehog (Shh) is a pleiotropic protein that plays a major role in most of the aforementioned processes during corticogenesis, including dorso-ventral patterning, the specification of interneurons and oligodendrocytes, as well as cortical circuitry formation (Fuccillo et al. 2006; Echelard et al. 1993; Ericson et al. 1995; Xu et al. 2005; Tekki-Kessaris et al. 2001; Harwell et al. 2012).

During mouse embryonic development, Shh is highly expressed in the ventral forebrain, where it plays a critical role in patterning during a specific developmental time window (embryonic days 9.5-12.5) (Xu et al. 2005; Fuccillo et al. 2004; Machold et al. 2003). Notably, changes in the concentration of Shh and the duration of Shh exposure influence the specification of different ventral progenitors and their neuronal progeny, which range from hypothalamic and striatal projection neurons to cortical and striatal interneurons (Maroof et al. 2013; Tyson et al. 2015). Despite the sparse expression of Shh in the mouse dorsal telencephalon (Dahmane et al. 2001), conditional inactivation of the Shh pathway leads to the defective proliferation of intermediate 
progenitor cells and to microcephaly (Komada et al. 2008). These results point to the concentration-dependent functions of this morphogen in both dorsal and ventral forebrain developments.

The significance of $S H H$ in human brain development is illustrated by the dramatic consequences of $\mathrm{SHH}$-pathway gene disruption, which include holoprosencephaly, seizure disorders, language or cognitive impairment, Down syndrome, hyperactivity, and schizophrenia (Heussler et al. 2002; Nanni et al. 1999; Belloni et al. 1996; Odent et al. 1999; Santiago et al. 2006; Currier et al. 2012; Betcheva et al. 2013). Many of these conditions are the result of $S H H$ haploinsufficiency, thus highlighting the importance of $\mathrm{SHH}$ gene dosage in humans (Chiang et al. 1996). Although in human embryos (Carnegie stages 12-16), the expression of $\mathrm{SHH}$ has been demonstrated ventrally, in the notochord, in the floorplate of the spinal cord, and in the hindbrain (Odent et al. 1999; Hajihosseini et al. 1996), there is a lack of information regarding the sources of SHH in the developing cerebral cortex.

A prerequisite for understanding the physiological role of SHH signaling during cortical development is the determination of its distribution and identification of its cellular sources in the prenatal human cortex. Our initial results, obtained in vitro, showed that at mid-gestation (around 20 gestational weeks, gw), $S H H$ is expressed by radial glia cells (RGCs) and that treatment with exogenous SHH favours the generation of $\mathrm{Nkx} 2.1^{+}$progenitors over calretinin $\left(\mathrm{CalR}^{+}\right)$ cells, while it has no effect on the generation of pyramidal neurons (Radonjic et al. 2016). In the present study, we used in situ hybridization (ISH) to analyze the distribution of $\mathrm{SHH}$-expressing cells in the prenatal human forebrain. We studied a wide spectrum of gestational ages ( $8-40 \mathrm{gw})$, using cryo-sections from throughout the rostro-caudal brain axis. We also combined fluorescence ISH (FISH) with cell-typespecific immunostaining and identified the cell types that express this morphogen. Finally, we analyzed, for the first time, the expression pattern of the known SHH receptors and downstream effectors in comparison with SHH expression in the early and late corticogenesis. These results contribute to the better understanding of cortical development and point to the importance of further studies of SHH signaling in neuropsychiatric disorders.

\section{Materials and methods}

\section{Human fetal brain tissue}

Human fetal brains $(n=30)$ from 8 to $40 \mathrm{gw}$ (gestational weeks correspond to postconceptional weeks; full term $=40$ gw) (Table S1) were obtained from the Human Fetal Tissue Repository at the Albert Einstein College of Medicine
(Bronx), Advanced Bioscience Resources (Alameda, CA), StemEx (Diamond Springs, CA, USA) and the joint MRC/ Wellcome Trust-funded Human Developmental Biology Resource (http://www.hdbr.org) after legal abortions with appropriate maternal written consent and approval from the Ethics Committees of the participating institutions. All human materials were handled with special care and following all necessary requirements and regulations set by the Ethics Committee of the University of Connecticut and the Helsinki Declaration. Fetal age was estimated on the basis of weeks after last period, crown-rump length, and anatomical landmarks. In all studied fetuses, ultrasound and gross neuropathological examination were used to exclude those with brain pathology. The dissected tissues were fixed in $4 \%$ formaldehyde solution in $0.1 \mathrm{M}$ phosphate buffer, cryoprotected by immersion in $30 \%$ sucrose, embedded in Tissue Tek (Sakura), frozen, and preserved in $-80^{\circ} \mathrm{C}$ until needed. The tissues used for in situ hybridization (ISH) and immunohistochemistry were cut into $15-\mu \mathrm{m}$-thick sections.

\section{In situ hybridization}

The human full-coding sequences (CDS) for GLI1, GLI2, GLI3, and PTCH 1 were purchased from Dharmacon. The human $S H H$ CDS was a gift from Cliff Tabin (Marigo et al. 1995) (pBS hShh CT\#401 Addgene \# 13996). For the SMO, $B O C, G A S 1$, and $C D O N$ probes, cDNAs from human fetal brain $(18 \mathrm{gw})$ were used as templates. The riboprobes were generated from a PCR fragment containing the transcription promoter sites T3/T7/SP6 (see Table S2), by in vitro transcription using digoxigenin (DIG)-UTP (Roche) as the label. ISH was performed as previously described (Radonjic et al. 2014). Briefly, cryo-sections (15 $\mu \mathrm{m})$ were dried at room temperature (RT) for $2 \mathrm{~h}$, fixed for 10 min with $4 \%$ paraformaldehyde (PFA), and washed twice in diethyl pyrocarbonate (DEPC)-treated phosphate buffer solution (PBS) before overnight incubation at $70^{\circ} \mathrm{C}$ in hybridization buffer containing $1 \times$ DEPC-treated "salts" $(200 \mathrm{mM} \mathrm{NaCl}, 5 \mathrm{mM}$ EDTA, $10 \mathrm{mM}$ Tris, pH 7.5, $5 \mathrm{mM}$ NaH2PO4.2H2O, $5 \mathrm{mM}$ Na2HPO4; Sigma-Aldrich), 50\% deionized formamide (Roche), $0.1 \mathrm{mg} / \mathrm{mL}$ of RNase-free yeast tRNA (Invitrogen, Carlsbad, CA, USA), $1 \times$ Denhardts (RNase/DNase-free; Invitrogen), 10\% dextran sulfate (Sigma-Aldrich) containing 100-500 ngmL of digoxigenin (DIG)-labeled RNA probe. After hybridization, the sections were washed three times in a solution containing $50 \%$ formamide $1 \times \operatorname{SSC}$ (salinesodium citrate, Invitrogen) and $0.1 \%$ Tween 20 (SigmaAldrich) at $65{ }^{\circ} \mathrm{C}$, and twice at RT in $1 \times$ MABT $(20 \mathrm{mM}$ maleic acid, $30 \mathrm{mM} \mathrm{NaCl}, 0.1 \%$ Tween 20; Sigma-Aldrich) before incubating in a solution containing $2 \%$ blocking reagent (Roche) and 10\% heat-inactivated sheep serum in MABT, followed by overnight incubation in alkaline-phosphatase-conjugated anti-DIG antibody (1:1500; Roche). 
Fast Red (Roche) was used for the fluorescent colorimetric detection of probe (FISH) by incubation in $100 \mathrm{mM}$ Tris, $\mathrm{pH}$ 8.2, $400 \mathrm{mM} \mathrm{NaCl}$ containing Fast Red for 1-2 h at $37{ }^{\circ} \mathrm{C}$. Alternatively, the TSA (tyramide signal amplification) kit (Perkinelmer) was used for FISH, in combination with anti-DIG-POD antibody (1:500, Roche). The sections were counterstained with bis-benzimide and cover-slipped using Fluoromount G mounting medium. The specificity of the procedure was assessed with a probe corresponding to the sense strand of the respective genes.

\section{Immunohistochemistry after ISH}

After ISH, sections were subjected to antigen retrieval in $0.1 \mathrm{M}$ citric acid, $\mathrm{pH} 9.0$, and blocked in $10 \%$ normal goat serum (NGS)/PBS containing $0.2 \%$ Triton (PBST). Following overnight incubation with primary antibody (see Table S3 for details), the sections were thoroughly washed in PBST and incubated with secondary Alexa 488- or Alexa 555-conjugated antibodies (Life Technologies) for $2 \mathrm{~h}$ at RT. Alternatively, an ABC kit was used followed by DAB development. Nuclei were counterstained for $5 \mathrm{~min}$ at RT with the nuclear stain bis-benzimide (Sigma).

\section{Quantification of immunolabeled cells}

Immunolabeled sections were visualized with an Axioscope microscope (Zeiss) equipped with Axiovision software and photographed using a digital camera. Three samples (22-24 gw) were used for the quantifications presented in Figs. 4 and 5. Nuclear staining allowed the delineation of areas of interest (e.g., CP, SVZ, IZ, and GE). Ten images for each region of interest were observed at $40 \times$ magnification and the number of cells was counted using the Photoshop CS6 Count Tool. A descriptive analysis of the data was performed using the Excel Data analysis plug-in. The percentages of double-positive cells expressing SHH are presented together with the standard error of the mean (SEM).

\section{Results}

\section{Distribution of SHH mRNA in the developing human forebrain}

Detailed information on the spatial distribution of SHH in the human developing brain is lacking, in part due to the limited availability of tissue and the failure of most commercially available antibodies to label SHH. We thus used ISH against the human coding sequence of $\mathrm{SHH}$ to follow expression during 7 months of the human gestational period (8-40 gw; Table S1). The expression of $S H H$ was highly dynamic, in accordance with the transcriptomics data available from the Allen Brain Institute (Fig. S1a, b). SHH expression in the fetal forebrain increased over the course of development and shifted from the proliferative ventricular (VZ) and subventricular zones (SVZ) (Fig. 1) to the overlying cortical layers (Fig. 2). At the earliest age studied (8-10 gw), Shh mRNA was predominantly restricted to the ventral forebrain, including the midline of the hypothalamus and thalamus, and to the emerging basal ganglia (Fig. 1a, e, f), in a similar pattern detected in the early embryonic mouse brain (Fig. S6a). By contrast, $S H H$ mRNA was only weakly expressed dorsally, in the cortical plate (CP) and cortical VZ (Fig. 1a, b), a result confirmed by TSA-FISH (tyramide signal amplification) and the absence of a signal with the sense probe (Fig. $1 \mathrm{~g}^{\prime}$ and S5). Furthermore, immunostaining with the rabbit monoclonal anti-SHH antibody (Farmer et al. 2016) revealed the definite presence of SHH protein in this area (Fig. 1g, g" and Fig. S1c-c"). The proximal choroid plexus (ChP) was also positive for the $S H H$ transcript and protein (Fig. 1h- $\mathrm{h}^{\prime \prime}$ ). Notably, the levels of SHH were much higher in ChP cells than in the nearby VZ, as observed by the differences in signal intensity at the different exposure times/settings (Fig. $\left.\mathrm{S} 1 \mathrm{c}-\mathrm{c}^{\prime \prime}\right)$. Thus, it cannot be ruled out that the positive signal for the SHH protein in the cortical VZ reflected the uptake of ChP-secreted SHH by RGCs. However, SHH immunostaining in the cortical VZ appeared in more frontal sections that are much further from the ChP (not present in the same section), suggesting that $\mathrm{SHH}$ is produced locally.

Another source of SHH protein in the developing human brain at this stage is the meninges, which were strongly positive for $S H H$ mRNA and protein. Within the meninges, $\mathrm{SHH}$-expressing cells were those of smooth-muscle lineage, rather than fibroblasts, as demonstrated by co-localization with smooth-muscle actin but not vimentin antibody (Fig. 1j, k). Finally, SHH mRNA was detected in the endothelial cells of blood vessels in the GE stained for the endothelial cell marker PECAM (CD31), indicating that the developing vasculature is an additional source of SHH (Fig. S1d-d"). Notably, endothelial cells in the ChP did not express $\mathrm{SHH}$ (Fig. 1i). Extracortically, SHH mRNA co-localized with SHH protein in the hypothalamic midline and retinal ganglion cells. In addition to validating the specificity of the antibody, this result provided insight into the range of SHH diffusion from its source (Fig. S1e-e", $\mathrm{f}-\mathrm{f}^{\prime \prime}$ ).

In the subsequent stages of development (15-17 gw), the density and distribution of $\mathrm{SHH}$ transcripts increased considerably throughout the forebrain (Fig. 2a, b; Fig. S2a). Strong signal was detected not only in the cortical VZ/SVZ (Fig. 2a"', b"; Fig. S2a), but also in the cortical plate (CP) (Fig. 2a', b; Fig. S2a), whereas the signal in the intermediate zone (IZ) and subplate (SP) increased dramatically from 15 to $17 \mathrm{gw}$ (Fig. 2a', b').

In the next stage of development, at mid-gestation (18-24 $\mathrm{gw}), \mathrm{SHH}$ expression increased steadily in subpopulations of 

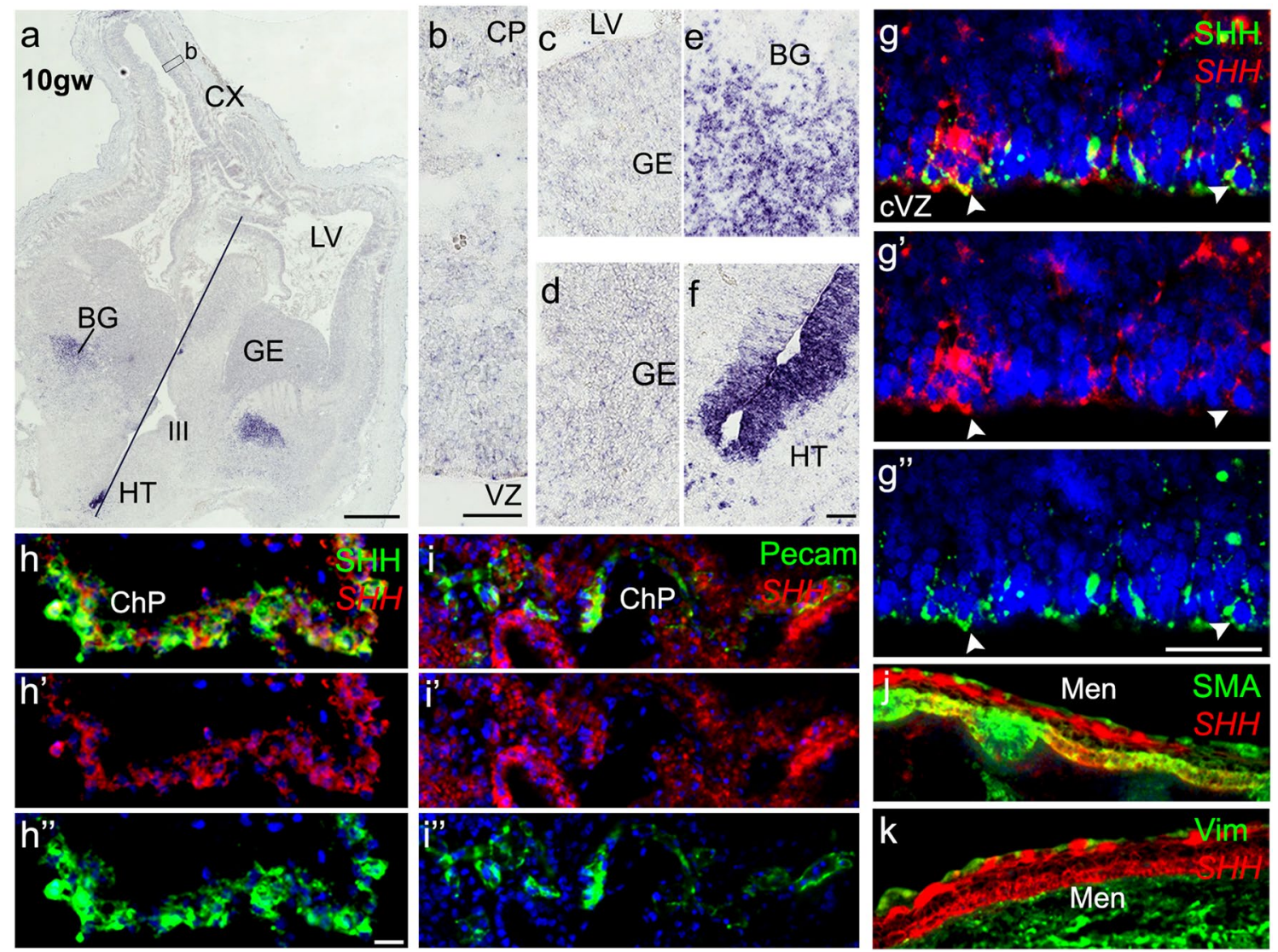

Fig. 1 Expression of Sonic Hedgehog $(\mathrm{SHH})$ in the human brain at 10 gw. a Coronal sections through both cerebral hemispheres show $\mathrm{SHH}$ mRNA signal in the diencephalon (hypothalamus, HT) and basal ganglia (BG). The line indicates the midline. b Low-level SHH expression in the developing cortex, mainly in the ventricular zone (VZ) and cortical plate (CP). c, d Scattered cells weakly expressing Shh in the VZ of the ganglionic eminence (GE) (c) and in other regions of the GE (d). e, f High-level expression in the future basal ganglia

cells in the expanded outer SVZ (oSVZ) (Figs. 3a, 6f), and in the IZ and SP, the zones through which neurons migrate (Figs. 2, 3a). At the same time, a very strong signal was present in cells located in the ganglionic eminence (GE) and hippocampus (Fig. 6j, S7c and Fig. S3). From 24 gw onwards, the $S H H$ transcript signal in the $\mathrm{cVZ}$ decreased progressively, coinciding with a reduction in the size of these structures in late fetal development. This is the first study demonstrating SHH expression in the GE and cVZI in stages after $14 \mathrm{gw}$. $\mathrm{SHH}$ expression in the upper cortical layers remained high between 24 and $27 \mathrm{gw}$ and persisted in the newborn (40 gw), in which SHH-expressing cells were found in all layers of the cerebral cortex (Fig. 2) and in the hippocampus (Fig. S3). A similar expression pattern was detected in mouse postnatal day 4 (P4) brain (Fig.S7d-d").

We then examined whether $S H H$ transcripts were present uniformly along the rostro-caudal and dorso-ventral axis or formed a gradient in these regions of the human (e) and hypothalamic midline (f). g-g" Both SHH protein (green) and transcript (red) are demonstrated in the cortical VZ in radial glial cells (arrowheads). h Choroid plexus expresses $S H H$ mRNA (red) and protein (green); single channels $\left(\mathbf{h}-\mathbf{h}^{\prime \prime}\right)$. i Pecam (CD31) immunostaining shows that endothelial cells in the choroid plexus do not express $S H H$ mRNA. j SHH-expressing cells stain with antibody to smooth-muscle actin (green) but not vimentin (green) (k). Scale bars: a $1 \mathrm{~mm}, \mathbf{b}, \mathbf{f}$ and $\mathbf{g} 50 \mu \mathrm{m}, \mathbf{h} 20 \mu \mathrm{m}$

fetal cortex. ISH performed in sagittal sections of 15 -gw forebrain showed that, although $\mathrm{SHH}$ expression appeared slightly higher in the rostral and caudal cortical areas than in the dorsal and ventral areas, the difference over the entire cortex was not significant (Fig. S2).

However, in later developmental stages (21-24 gw), SHH expression exhibited a high rostral to lower caudal gradient, as illustrated in coronal sections prepared from rostral (frontal), medial, and caudal (occipital) tissue blocks of the 23-gw fetal forebrain (Fig. 3a). Moreover, within each tissue block, $S H H$ signal intensity was consistently stronger in dorsal than in ventral cortical areas (Fig. 3a).

In addition, cortical $S H H$ expression exhibited regional differences, as illustrated in single coronal sections prepared through the level of the thalamus. The signal was always stronger above the insular region of the cortex, in the prospective somatosensory/motor cortices and possibly including Broca's area (Fig. 3b:1-4), than in the ventrally 


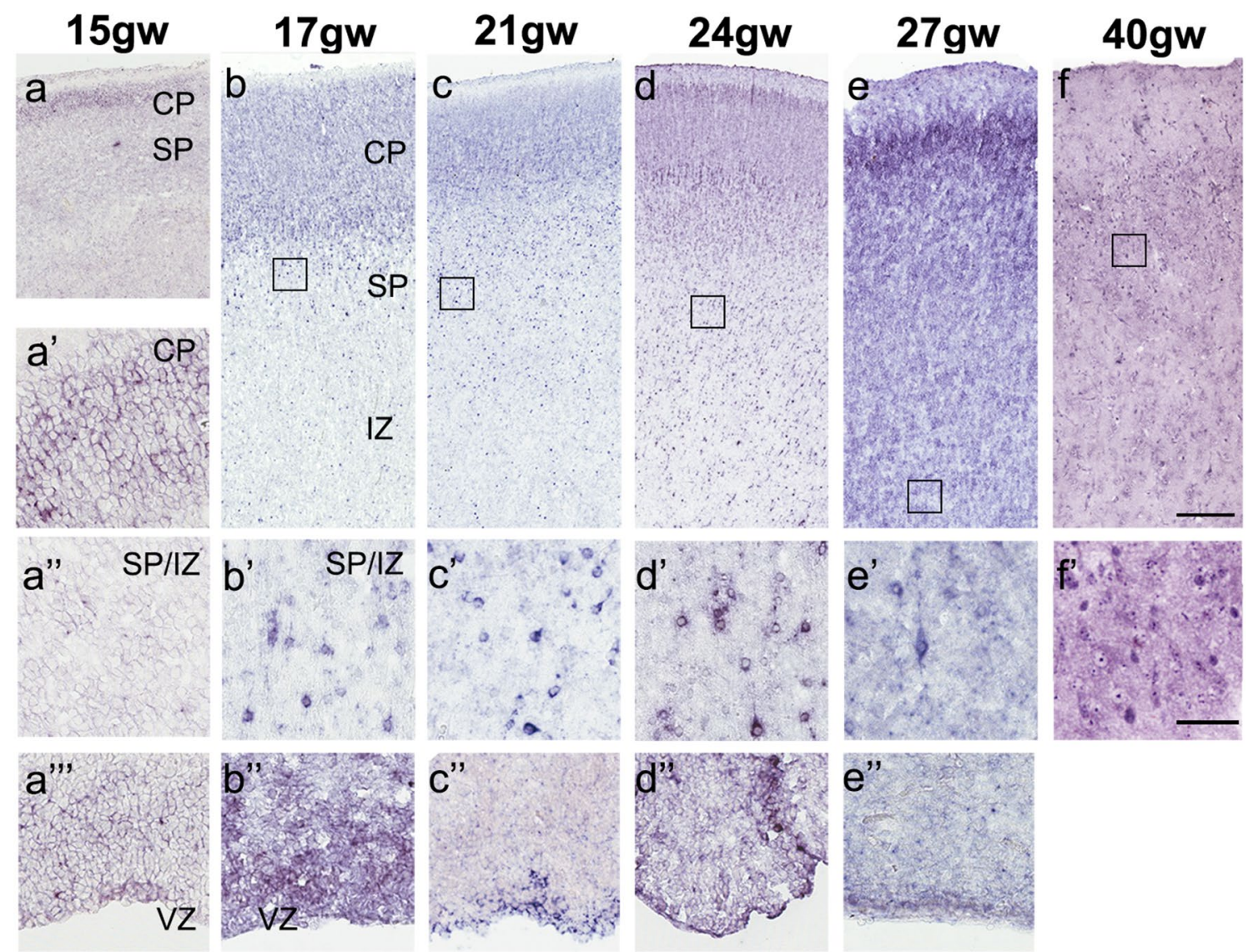

Fig. 2 Spatiotemporal changes in SHH expression in the human cerebral cortex between 15 and 40 (newborn) gw. a-f Low magnification of the cortical column at the indicated age. $\mathbf{a}^{\prime \prime}-\mathbf{f}^{\prime}$ High magnification of cells in the subplate (SP)/intermediate zone (IZ) area (indi-

positioned temporal cortex (Fig. 3b:6-7). This pattern, which first emerged around $19 \mathrm{gw}$ and became prominent at 22-24 gw, confirms the transcriptome data (Fig. S1a, b) that suggest higher expression in the dorsal than ventral cortex for this developmental stage.

These results revealed the complex pattern of $\mathrm{SHH}$ expression in the developing cortex and thus a possible role for $\mathrm{SHH}$ in cortical arealization during the second and third trimesters of gestation.

\section{Characterization of SHH-expressing cells during mid-gestation}

After establishing that $S H H$ mRNA is expressed widely in fetal brain, we asked which cell types express $S H H$ in the developing human cortex. The answer to this question is important, because it might indicate the roles played by $\mathrm{SHH}$ during development. We, therefore, subjected the fetal tissue sections to FISH followed by immunohistochemistry with cell-type-specific markers. Specifically, we asked whether during the late second trimester of gestation (20-24 gw).

cated boxes). $\mathbf{a}^{\prime \prime \prime}-\mathbf{e}^{\prime \prime}$ High magnification of cells in the cortical VZ (except at $40 \mathrm{gw}$,when there is no VZ). $C P$ cortical plate. Scale bars : f $200 \mu \mathrm{m}, \mathbf{f}^{\prime} 50 \mu \mathrm{m}$

SHH transcripts are expressed by cortical progenitors, that is, RGCs, which are the predominant cell type in the proliferative VZ/SVZ. Using the RGCs markers Pax6, GFAP, and vimentin, we identified cells that co-express $S H H$ mRNA as well as these markers (Fig. 4). Moreover, many of the $\mathrm{SHH}$-expressing cells were proliferating, based on their colabeling for the proliferation marker Ki67 (Fig. 4c). Quantification of the double-labeled cells showed that $89 \%( \pm 5.19$ SEM, $n=3$ ) of the Pax6-positive cells in the VZ expressed SHH transcripts, compared to $69 \%( \pm 6.6 \mathrm{SEM}, n=3)$ in the SVZ; thus, at this developmental stage the majority of RGCs in the proliferative zones produced SHH (Fig. 4e).

Since progenitors in the fetal cortex give rise mainly to glutamatergic neurons, $\mathrm{SHH}$-expressing cells in cortical layers were probed with the glutamatergic cell marker Tbr1 (T-box Brain 1) to determine whether they belong to this neuronal population (Fig. 5a-a"', b). From the total population of $\mathrm{Tbr}^{+}$cells in the subplate and the IZ, around $70 \%$ $(n=3)$ were positive for $S H H$ (Fig. $5 b)$. Thus, in addition to RGCs in the VZ/SVZ, a subpopulation of glutamatergic neurons in cortical layers is source of SHH. This finding was 

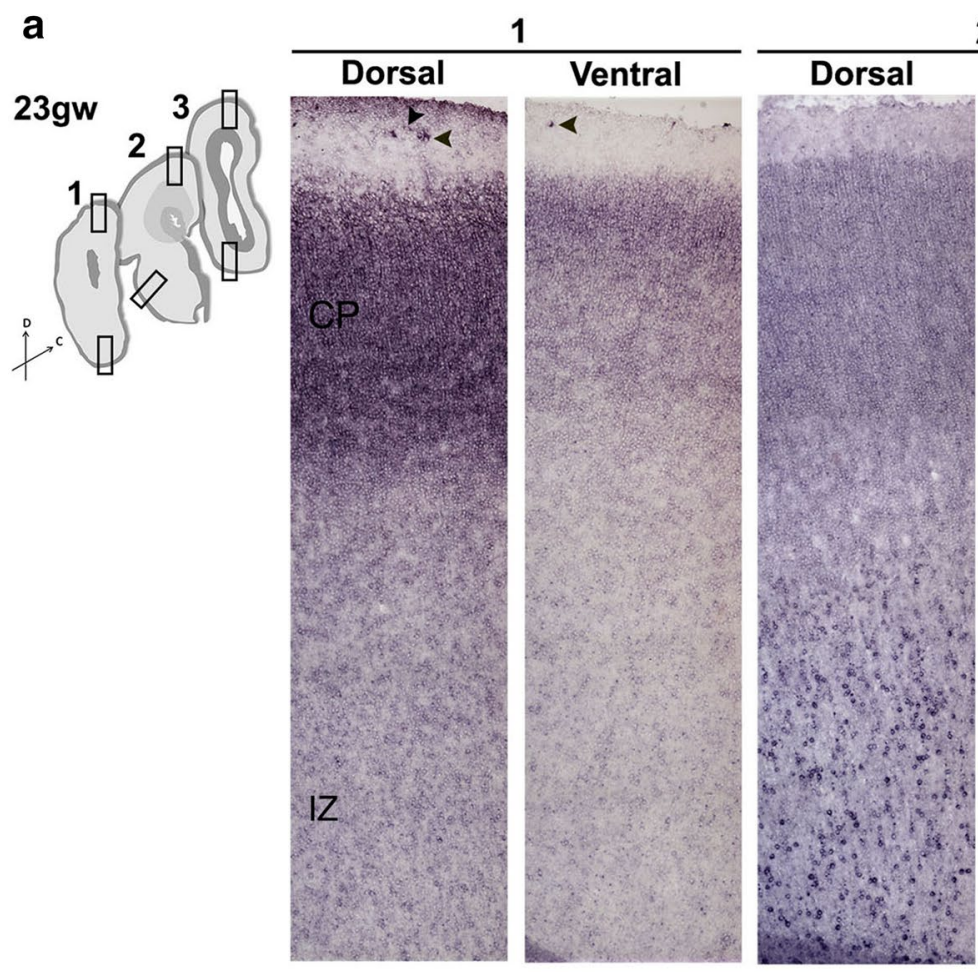

2
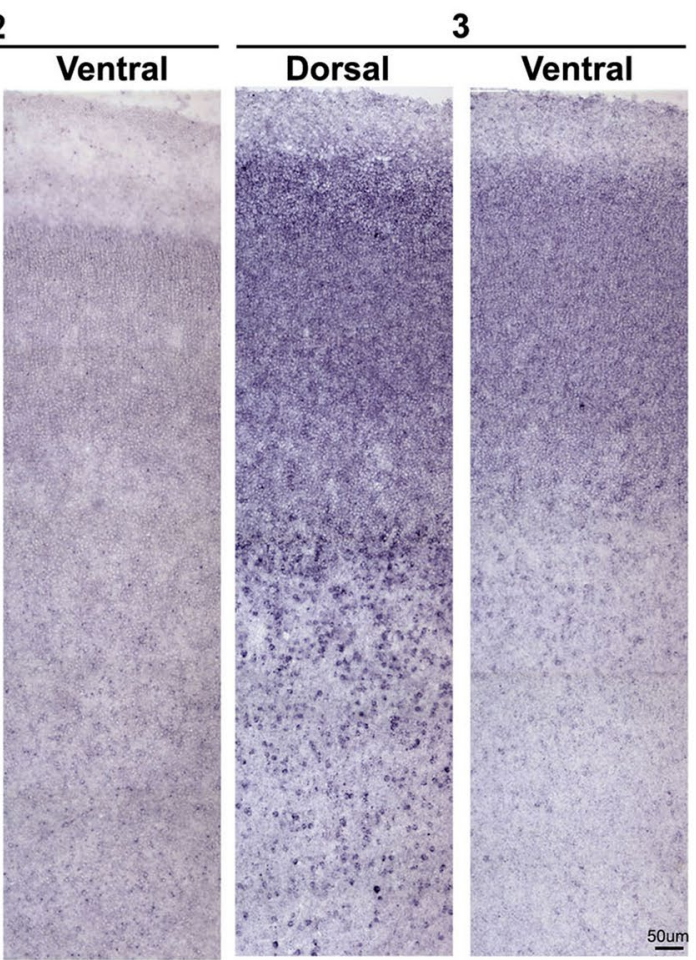

b

24gw
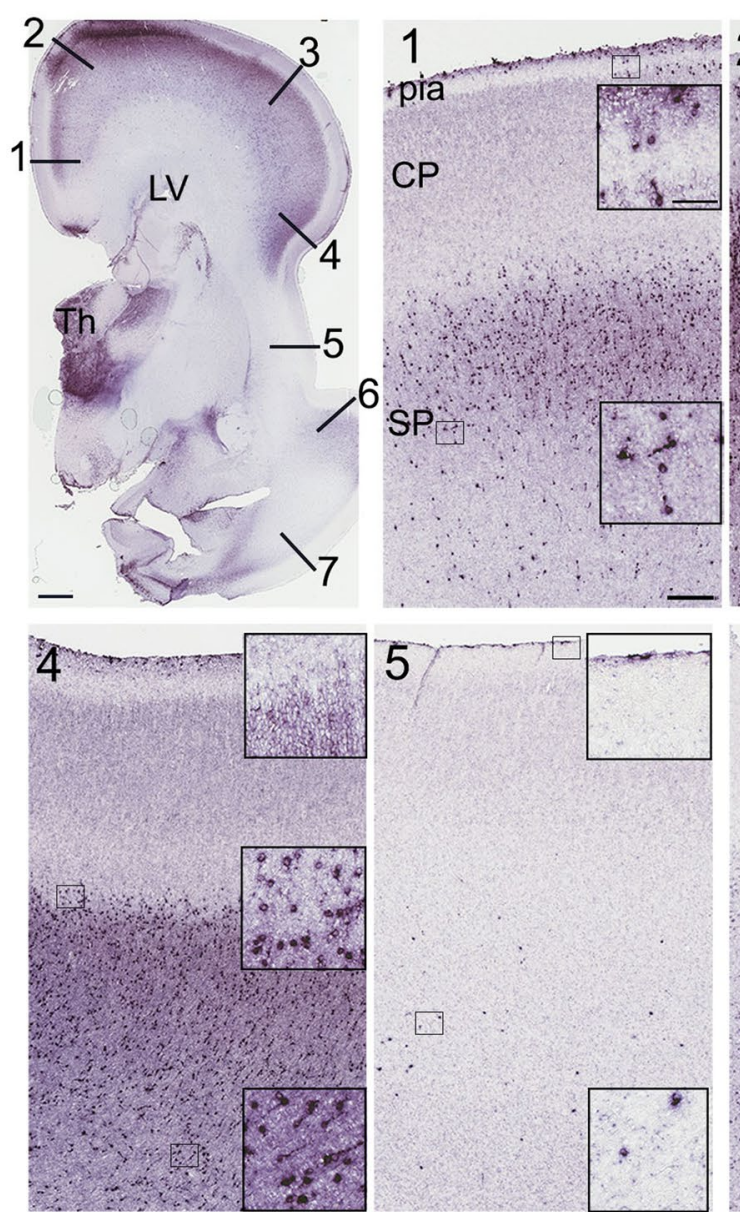
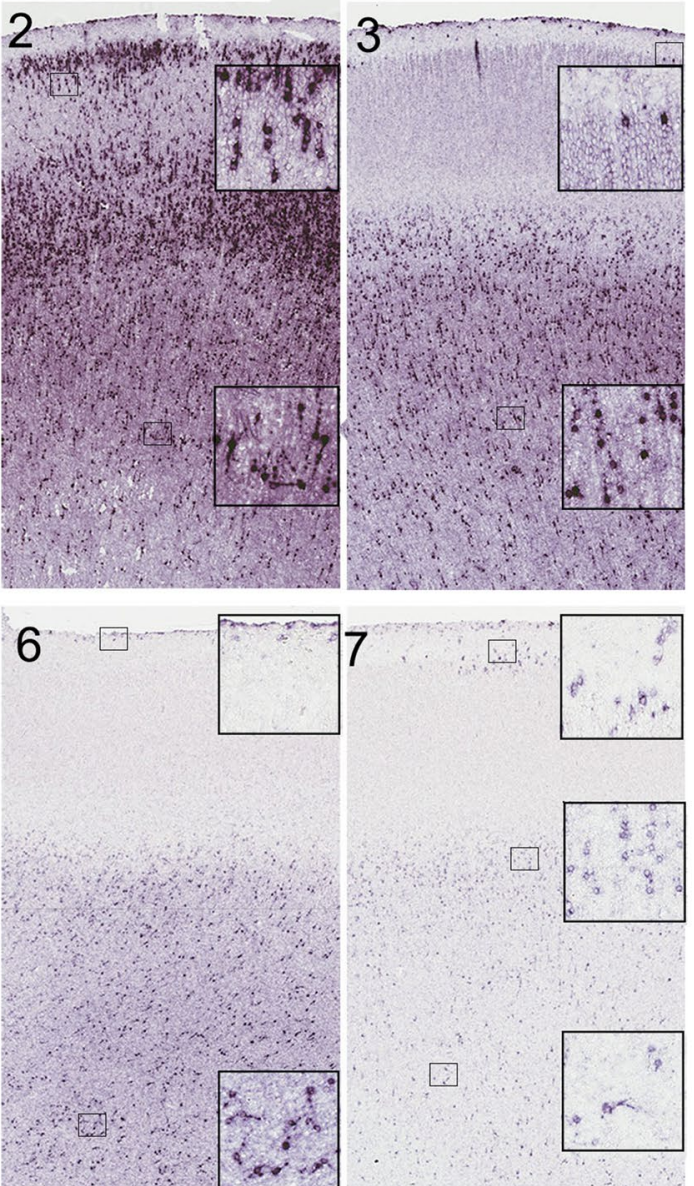
4Fig. 3 Gradients of SHH mRNA in 23-24 gw brains. a Coronal sections from three tissue blocks (1-3) from frontal to occipital pole show rostro-caudal gradient of $\mathrm{SHH}$ mRNA expression. In addition, dorsal areas show higher expression than ventral in each block. b In a single coronal section, the expression of $\mathrm{SHH}$ transcripts shows pronounced differences (1-7). Boxed ares show higher magnification along the cerebral cortex. 1 Cingulum; 2-3 dorsal cortex, future somatosensory or motor areas; 4 frontal, preinsular cortex; 5 insula; 6-7 temporal cortex. Scale bars: a $50 \mu \mathrm{m}$, b $2 \mathrm{~mm}$, (1) $250 \mu \mathrm{m}$ and inset $50 \mu \mathrm{m}$

confirmed using another marker for deep cortical layer neurons, CTIP2 (Fig. 5c). Two more general neuronal markers, Map2 and NeuN, were also co-expressed with $S H H$ transcripts in a subpopulation of cortical neurons (Fig. 5d, e).

Co-labeling with GABA (Fig. 5f) or Gad65/67 (Fig. S4a, $\left.\mathrm{a}^{\prime}\right)$ suggested that at mid-gestation, cortical interneurons are less likely to express $S H H$ transcript than glutamatergic neurons. Since not all $\mathrm{SHH} \mathrm{mRNA}^{+}$cells overlap with neuronal markers in higher cortical layers, we investigated whether non-neuronal populations in the cortex also express $\mathrm{SHH}$ transcript. Indeed, $\mathrm{GFAP}^{+}$astrocytes in the IZ and SP/CP expressed $\mathrm{SHH}$ (Fig. 4d), but not oligodendrocytes or microglia labeled with Olig2 or Iba1, respectively (Fig. S4b, c). These data are consistent with a heterogeneous cell population producing Shh during mid-gestation, with the two main sources being RGCs and glutamatergic neurons.

\section{SHH-signaling pathway in the developing human cortex}

Despite the demonstration of the widespread expression of $S H H$ in the developing human cortex, whether the classical $S H H$ pathway was activated remained to be tested. Gli1 (GLI zinc finger transcription factor), a transcription factor activated by Shh-signaling, is the most sensitive and reliable read-out for this pathway as, unlike Gli2 and Gli3, it acts only as an activator (Bai et al. 2004). The presence of GLII would, therefore, provide proof that the expressed $\mathrm{SHH}$ activates the signaling pathway in nearby cells. ISH using the human GLI1 probes on sections from fetuses age 19-24 gw found that the GLII transcript was expressed in the cortical VZ and CP/SP as well as in the GE (Fig. 6a-d). The intensity of the GE signal was much stronger, indicating a higher level of $\mathrm{SHH}$ expression, and hence SHH-signaling activity, in this area. GLI3, a transcription factor that acts as both a repressor and an activator of the Shh pathway (Ingham and McMahon 2001), was highly expressed in the cortical VZ, in the inner and outer SVZ (Fig. 6e, g-h), and in the hippocampus (Fig. 6i), confirming previously published transcriptomics data showing that GLI3 is expressed by human RGCs (Pollen et al. 2015).

We then asked whether the SHH receptor PATCHED1 (PTCH1) is expressed in the vicinity of $\mathrm{SHH}$-expressing cells. We tested tissues from fetuses of two gestational ages, early (10 gw), when cell proliferation, migration, and neurogenesis/fate specification are predominant, and later, at mid-gestation (19-24 gw), when additional processes such as axonal guidance and synaptogenesis occur. At 10 gw, PTCH1 transcripts were non-detectable in the neocortex (Fig. 7b, b'), while expression was low in the VZ of the GE and in the thalamic and hypothalamic neuroepithelium, paralleling the spatiotemporal pattern of strong $\mathrm{SHH}$ expression in these ventral regions. At later stages (19-24 gw), when $\mathrm{SHH}$ expression increased in the cortex, PTCHI was seen in the cortical VZ, although at much lower levels than in ventral areas such as the GE or hypothalamus (Fig. 7h, h'). Immunostaining with PTCH1 antibody verified low- and high-level expression in the cortical VZ and GE, respectively (Fig. 7m, n). Co-labeling with GFAP also demonstrated the expression of this receptor by RGCs in the cortical VZ (Fig. 7m'). A weak PTCH1 mRNA signal was detected in the dentate gyrus of the hippocampus (Fig. S3h).

In addition to Ptch1, three other membrane-associated proteins, the structurally related Boc (biregional Cdonbinding) and Cdon (cell-adhesion-molecule-related/downregulated by oncogenes) proteins and the vertebrate-only Gas1 (growth-arrest-specific 1) protein, are thought to function as positive modulators of Shh signaling by enhancing the presentation of Shh to its receptor, Ptch1 (Tenzen et al. 2006; Allen et al. 2007; Martinelli and Fan 2007). Both Boc and Cdon promote Shh-dependent cell-fate specification and axon guidance (Tenzen et al. 2006; Okada et al. 2006), while Gas 1 regulates the ventral specification of neural tube progenitors (Allen et al. 2007; Martinelli and Fan 2007) and CGNP (cerebellar granule neural progenitors) proliferation (Liu et al. 2001). Boc, Gas1, and Cdon are required for successful Shh signaling (Izzi et al. 2011). We found that $B O C$ and $G A S 1$ were strongly expressed at $10 \mathrm{gw}$ in cortical $\mathrm{VZ}$ and GE, whereas $C D O N$ was present only in the cortical VZ (Fig. 7c-e). GAS1 was also expressed in the CP at this stage. The ChP cells, however, express only BOC at 10 gw (Fig. S8b). At later stages (19-24 gw), the expression of $B O C$ and $C D O N$ was similar to that in earlier stages: high in the cortical VZ and SVZ and low in the CP/SP and GE (Fig. 7i-i', j-j'). GAS1 expression in the CP was lower than at $10 \mathrm{gw}$, but remained high in the cortical VZ, oSVZ, and GE (Fig. 7k-k'). Finally, expression of the SHH signal transducer, SMO (smoothened) was weak in the 10-gw brain (Fig. 7f, $\mathrm{f}^{\prime \prime}$ ), but increased in the 19-gw cortical VZ and in the CP (Fig. 71-1'). SMO expression was also detected in the 10-gw ChP (Fig. S8a). Thus, in summary, all three receptors $(B O C, C D O N$, and $G A S 1)$ were expressed in the $\mathrm{VZ}$ during early fetal development, pointing to their role in cell proliferation. $C D O N$ and GAS1 were expressed at higher levels than $B O C$ in the $\mathrm{CP}$, suggesting their additional roles in cortical development. 

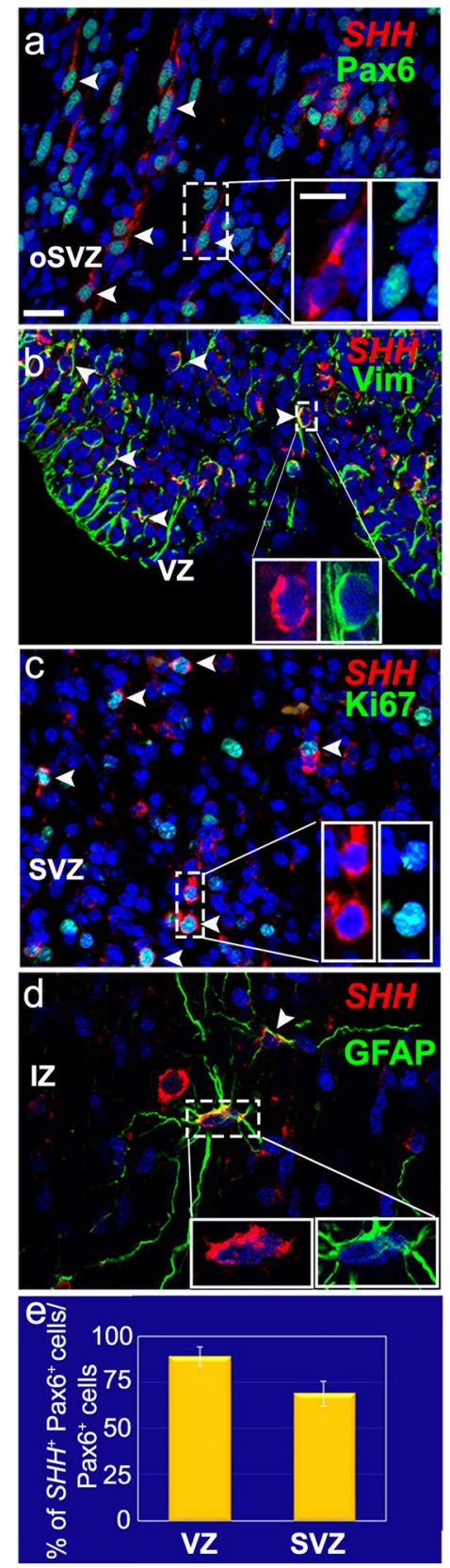
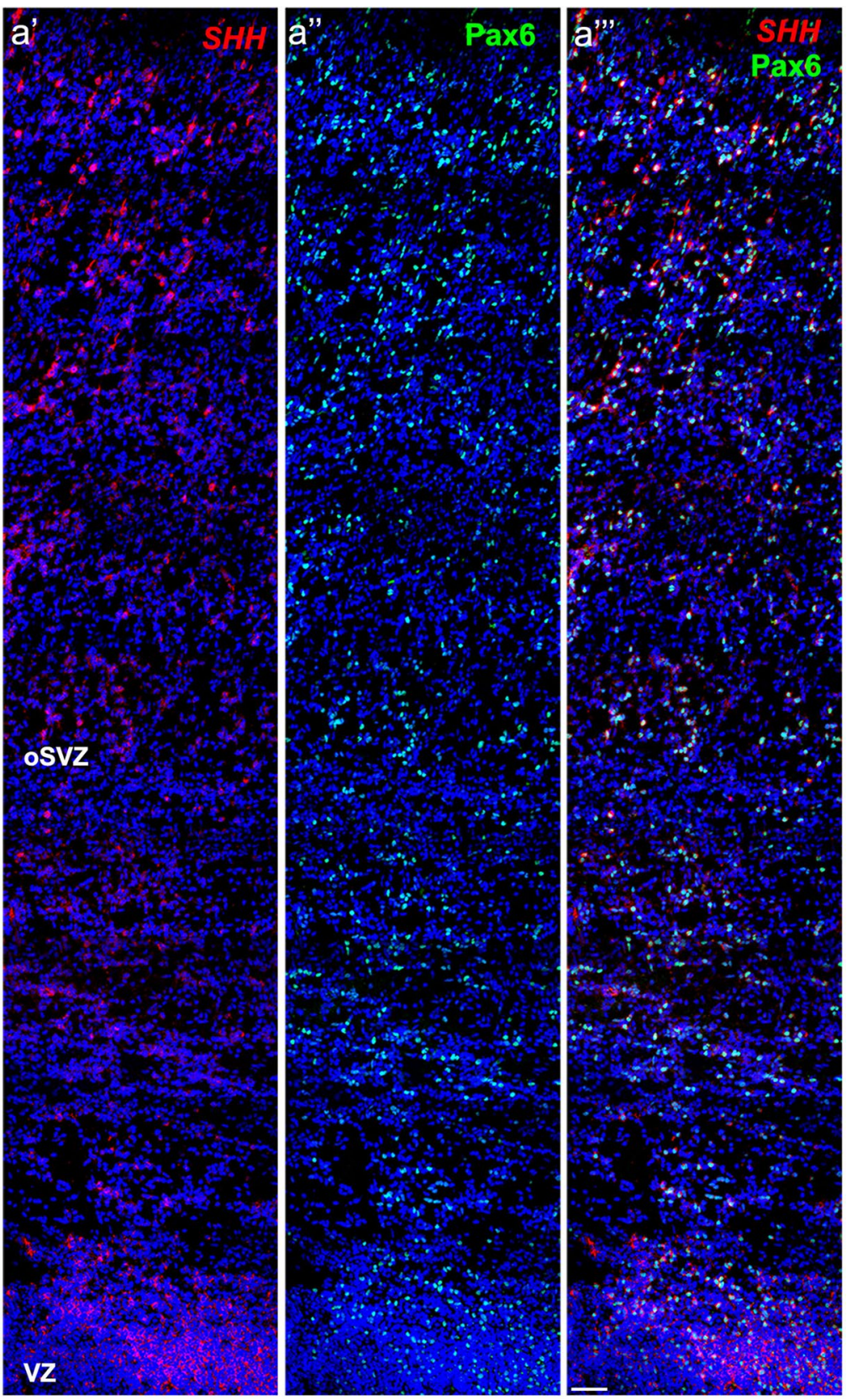

Fig. 4 Cell-type-specific expression of $S H H$ transcript in the 18-24gw fetal brain. $\mathbf{a}^{\prime}-\mathbf{a}^{\prime \prime \prime}$ Combined ISH for $\mathrm{SHH}$ (red) and immunostaining for Pax6 (green) show numerous radial glial cells (RGCs) that co-localize $\mathrm{SHH}$ transcript and Pax6 in the proliferative zones (VZ and subventricular zone, SVZ). a-inset Higher magnification of co-labeled cells in the outer SVZ (oSVZ) (arrowheads). b Vimentin staining for RGCs (green) after ISH for $\mathrm{SHH}$ (red) confirms that

\section{Discussion}

SHH is crucial for human brain development and changes in its signaling lead to distinct neuropathologies (Heussler et al. 2002; Nanni et al. 1999; Belloni et al. 1996; Odent et al. 1999; Santiago et al. 2006; Currier et al. 2012). Despite
RGCs in the VZ express $S H H$ (arrowheads). c Numerous proliferating $\mathrm{SHH}^{+}$cells, indicated by $\mathrm{Ki} 67$ co-expression. The inset shows a higher magnification of the boxed area. $\mathbf{d}$ Mature astrocytes $\left(\mathrm{GFAP}^{+}\right)$ in the IZ/SP express $S H H$ mRNA. e Percentage of total Pax6 ${ }^{+}$cells that co-express $\mathrm{SHH}$ (red) in the VZ $(89 \% \pm 5.19$ SEM) and SVZ $(69 \% \pm 6.6 \mathrm{SEM})$ of $22-24$-gw tissues $(n=3)$. Scale bars: a $25 \mu \mathrm{m}$, a-inset $10 \mu \mathrm{m}, \mathbf{a}^{\prime \prime \prime} 50 \mu \mathrm{m}$

its importance, information on $\mathrm{SHH}$ expression profile in the developing human brain is still fragmentary. Here, we provided evidence of the expression of $\mathrm{SHH}$ and the transcription factors, and receptors necessary for its signaling, in specific cortical layers and cell types. Our study spans the course of most of the gestational period. The spatiotemporal 

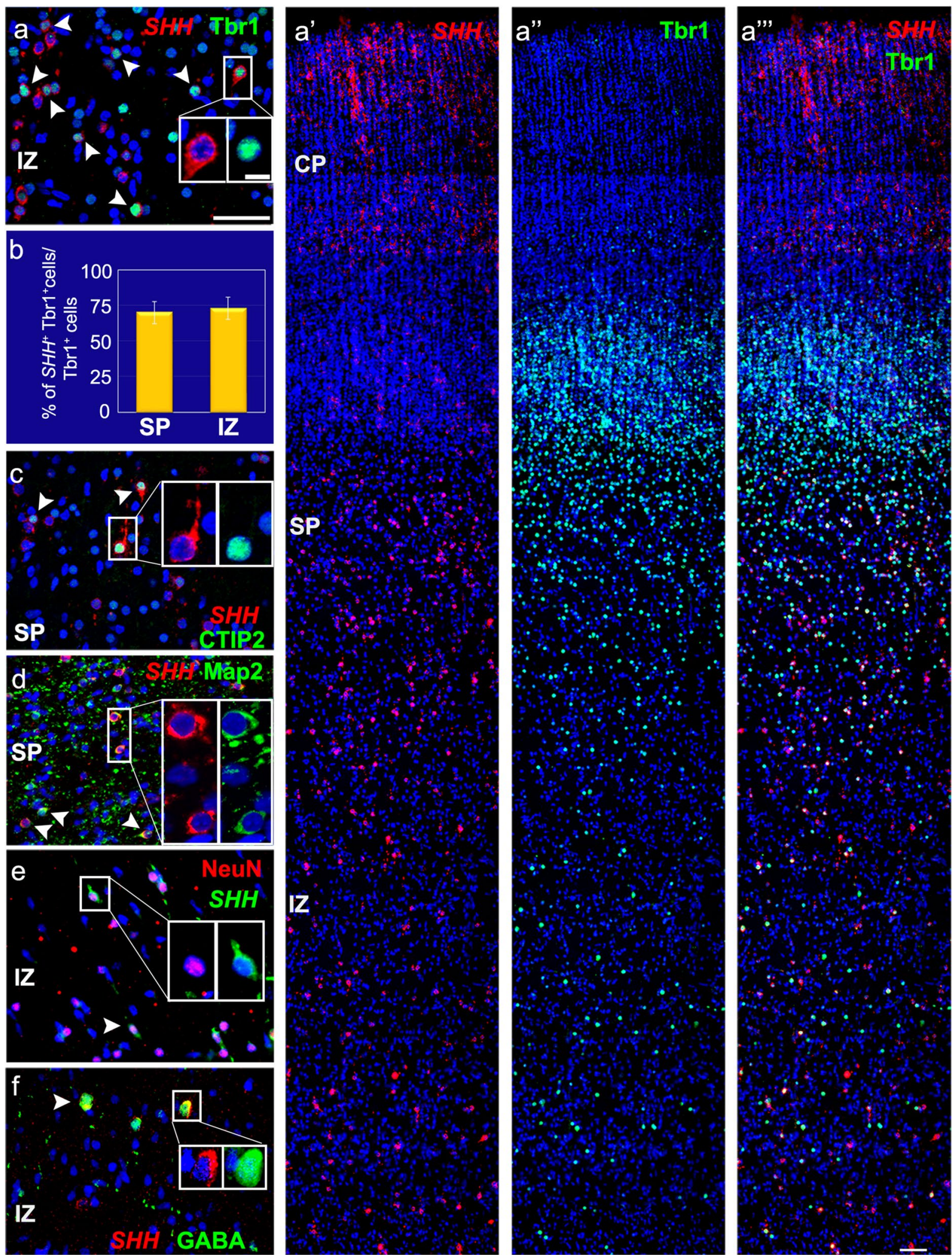

\section{SP}
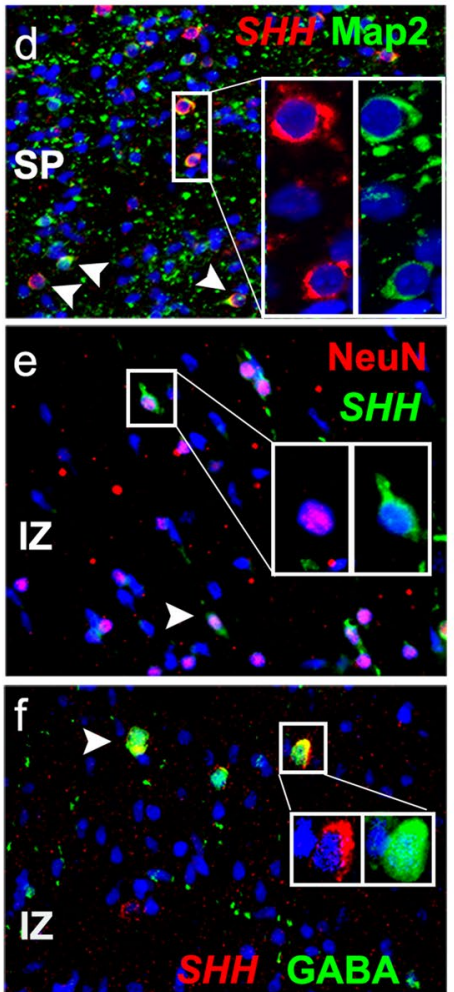

IZ

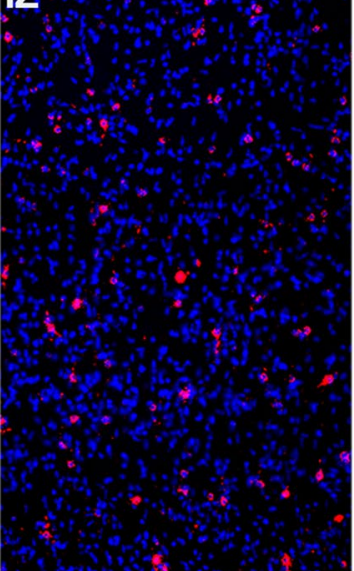

Fig. 5 Various subtypes of neurons express $S H H$ in the 18-24 gw cortex. a-a"' Co-labeling for SHH mRNA (red) and Tbr1 (green) reveals many postmitotic projection neurons across the SP and IZ expressing SHH. a', a" Single channels. b Percentage of $\mathrm{Tbr}^{+}$ cells expressing $\mathrm{SHH}$ in the SP $(70 \% \pm 7.6 \mathrm{SEM})$ and IZ $(73 \% \pm 7.8$ SEM) in 22-24-gw sections $(n=3)$. c-f $S H H$ is expressed by neurons labeled with CTIP2 (c), MAP2 (d), NeuN (e), and GABA (f). Scale bars: $\mathbf{a}$ and $\mathbf{a}^{\prime \prime \prime} 50 \mu \mathrm{m}$, a-inset $10 \mu \mathrm{m}$ 

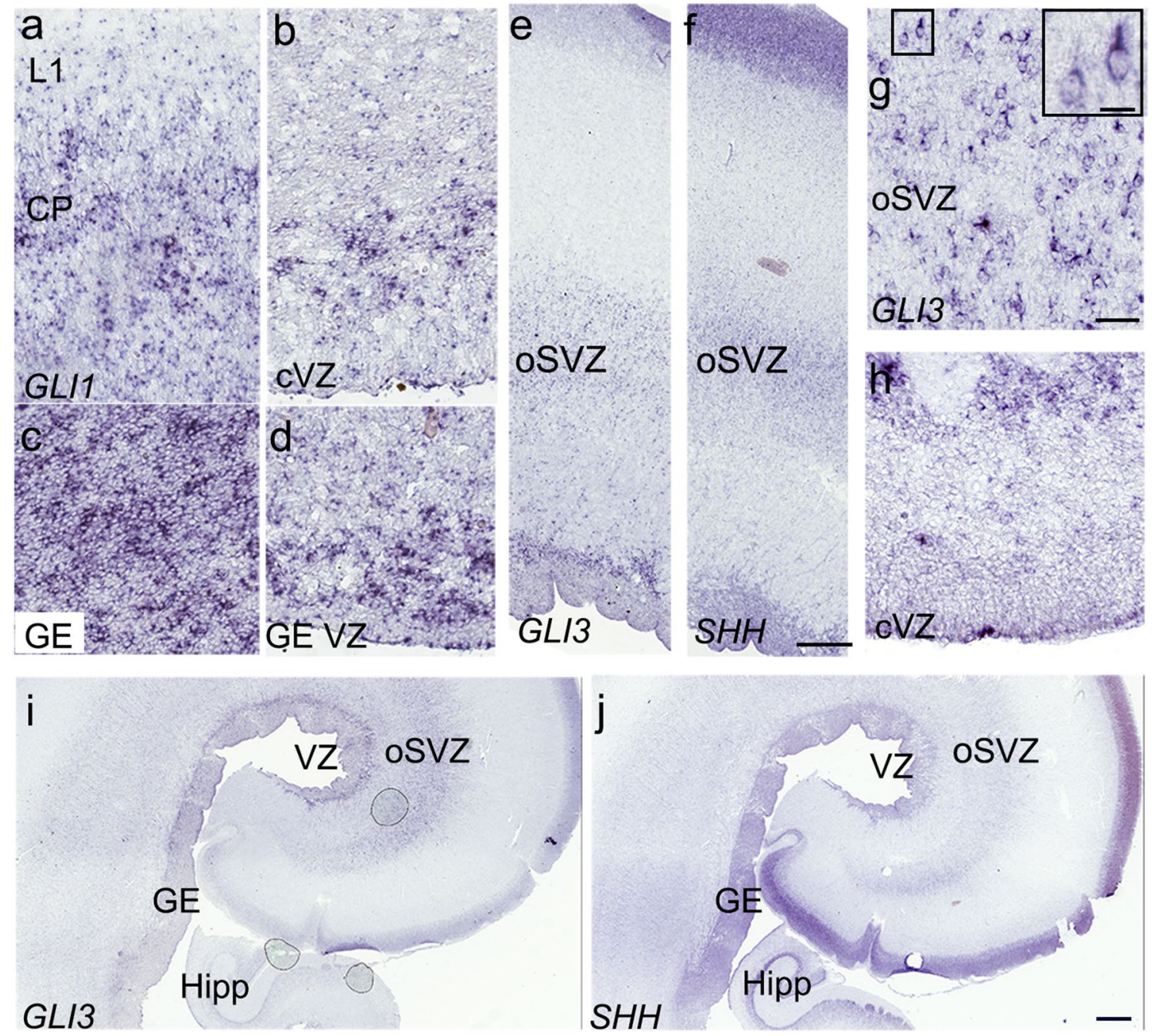

Fig. 6 Components of the SHH-signaling pathway are expressed in the human fetal cortex at $22 \mathrm{gw}$. a, b ISH reveals the cortical expression of GLII (CP and VZ), indicative of SHH-signaling activity in these areas. c, d Strong GLII expression in the GE suggests higher levels of SHH activity ventrally. e, f GLI3 and $S H H$ transcripts show similar high-density signals in the VZ and oSVZ. g On higher mag-

distribution suggests the involvement of SHH in diverse developmental processes in the human telencephalon, including cell proliferation and cell-fate specification in the VZ/SVZ, the subsequent migration of newly generated neurons, synaptogenesis, and circuit formation.

Our results agree with those of the previous studies (Odent et al. 1999), in which $S H H$ mRNA was mostly detected in the ventral structures of the human brain during early stages $(8-10 \mathrm{gw})$, with very low signal in the developing cerebral cortex. Given that a high concentration of SHH is known to induce patterning and cell-fate specification, whereas low levels regulate proliferation (Komada 2012; Komada et al. 2008; Wang et al. 2016a, b) this pattern of signal localization suggests that $\mathrm{SHH}$ regulates patterning nification, $\mathrm{GLI}^{+}$cells in the oSVZ resemble RGCs and are more numerous than in the VZ (h). i, $\mathbf{j}$ Comparison of the GLI3 and $S H H$ expression patterns in adjacent coronal sections at the level of the hippocampus (Hipp) of the $22 \mathrm{gw}$ fetal brain. Scale bars: f $500 \mu \mathrm{m}, \mathbf{g}$ $50 \mu \mathrm{m}, \mathbf{g}$ - inset $15 \mu \mathrm{m}, \mathbf{j} 1 \mathrm{~mm}$

and cell-fate specification in the human ventral forebrain and proliferation in the dorsal forebrain. $S H H$ transcripts were clearly detected in the cortical VZ/SVZ at $15 \mathrm{gw}$, which is consistent with our previous in vitro results showing that this morphogen is secreted by dorsal RGCs and induces their proliferation (Radonjic et al. 2016). The function of Shh in proliferation and regulation of symmetric/asymmetric divisions of intermediate progenitors in mice (Dave et al. 2011) points to a role as a mitogen in the human cortical proliferative zone. This role is probably maintained even past mid-gestation, since neurogenesis in humans continues up to $27 \mathrm{gw}$, later than previously known (Malik et al. 2013). Between 15 and $27 \mathrm{gw}, \mathrm{SHH}$ was also expressed in the IZ, $\mathrm{SP}$, and $\mathrm{CP}$, where the intensity of the signal increased over 


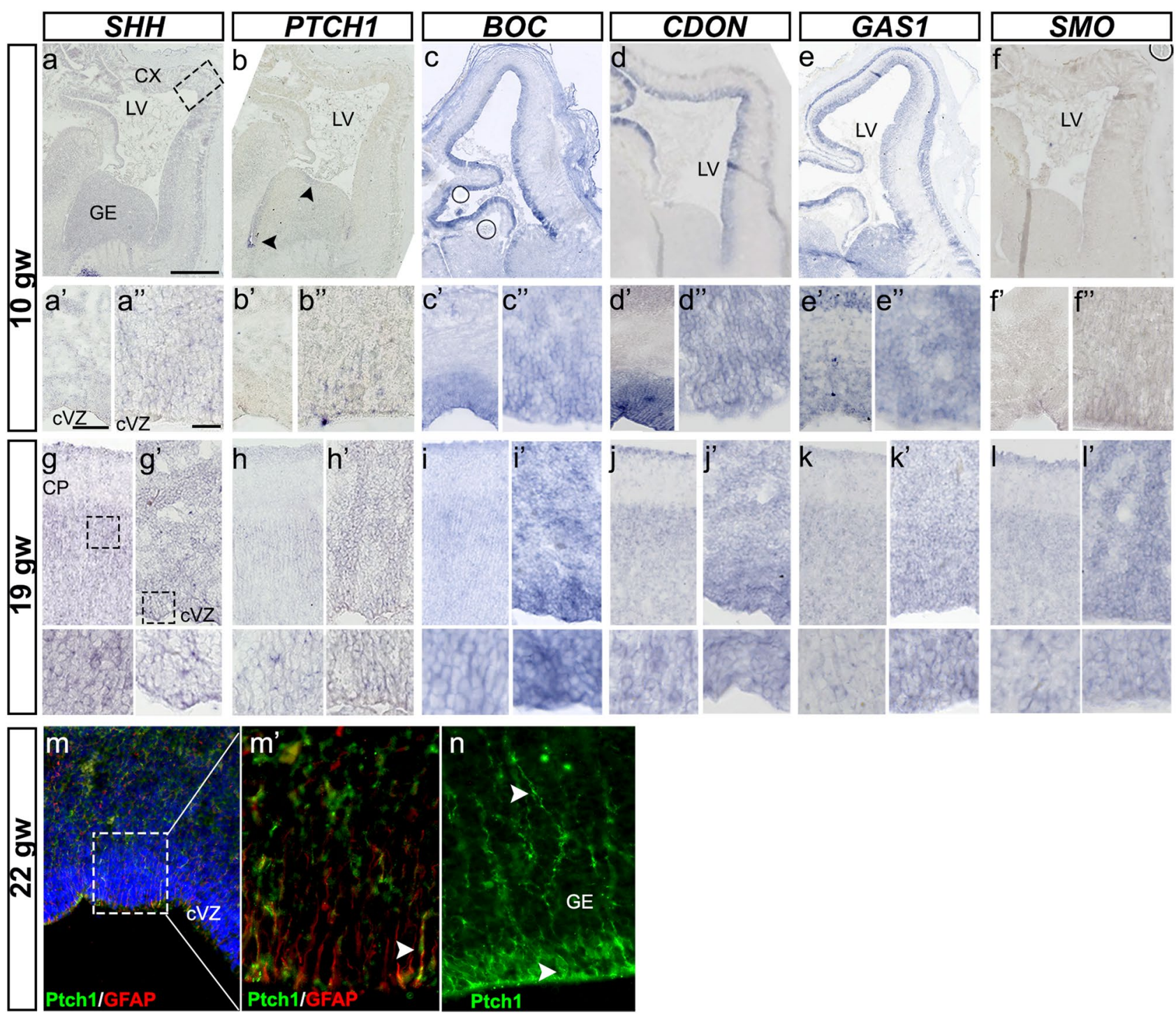

Fig. 7 Expression of SHH receptors in the fetal human brain at 10 and 19 gw. a-a" ISH for $S H H$ on a coronal section from a $10-\mathrm{gw}$ brain, as a reference for all SHH receptors in sections from the same fetus. Higher magnification of the boxed areas in (a): $\mathbf{a}^{\prime}$ cortex, $\mathbf{a}^{\prime \prime}$ cVZ. Weak signal is detected in the cortical VZ and GE. b-b" ISH for $P T C H 1$ receptor reveals very low expression in the $\mathrm{VZ}\left(\mathbf{b}^{\prime \prime}\right) . B O C$ expression is much more prominent along the cortical VZ and GE VZ $\left(\mathbf{c}-\mathbf{c}^{\prime \prime}\right)$, whereas $C D O N$ expression is restricted to the cortical VZ (d$\left.\mathbf{d}^{\prime \prime}\right)$. GASI is the only receptor expressed in both the $\mathrm{VZ}$ and $\mathrm{CP}$, in

time. Furthermore, we observed robust inter-regional and areal differences in the expression of $\mathrm{SHH}$ during mid-tolate gestation in fetal neocortex. Although it is difficult to interpret this spatiotemporal expression pattern, these differences most likely have biological origin and they are not due to tissue quality or other variation as observed in all cases studied. The $\mathrm{SHH}$-positive cells in developing cortical layers were mostly neurons expressing Map2 or NeuN, with a subpopulation expressing glutamatergic markers (Tbr1 or CTIP2), as previously reported for the early postnatal addition to the GE (e-e $\left.\mathbf{e}^{\prime \prime}\right)$. SMOOTHENED $(S M O)$ is hardly detected in the VZ at this stage $\left(\mathbf{f}-\mathbf{f}^{\prime \prime}\right)$. $\mathbf{g}-\mathbf{l}^{\prime} S H H$ and all its receptors in contiguous sections of $19-\mathrm{gw}$ brain. Two areas are presented for each gene: CP and VZ/SVZ. m Co-staining of 22 -gw brain with Patched1 and GFAP antibodies shows that RGCs in the cortical VZ express this receptor. $\mathbf{m}$ ' Higher magnification of the boxed area in $(\mathbf{m})$. $\mathbf{n}$ Ptch1 immunoreaction in the same section reveals a strong expression in the GE. a $1 \mathrm{~mm}, \mathbf{a}^{\prime} 150 \mu \mathrm{m}, \mathbf{a}^{\prime \prime} 25 \mu \mathrm{m}$

mouse brain (Harwell et al. 2012). The SHH transcript was also identified in a subpopulation of GABAergic cells, in accordance with the results of a single study in mouse (Komada et al. 2008). Given that Shh in mice plays a role in neuronal migration, axonal guidance (Fuccillo et al. 2006; Baudoin et al. 2012; Bourikas et al. 2005; Charron et al. 2003; Yam et al. 2009), and synaptic connectivity (Harwell et al. 2012), it is likely that it has similar functions in the developing human fetal neocortex. Moreover, the finding that GFAP-labeled astrocytes in the upper IZ, SP, and CP 
were positive for $\mathrm{SHH}$ suggests a role in numerous processes in which astrocytes are involved, such as synapse formation and synaptic plasticity (Farmer et al. 2016; Eroglu and Barres 2010) as well as the formation and maintenance of the blood-brain barrier (BBB). Indeed, recent work demonstrated that Hedgehog signaling promoted the formation and integrity of the BBB as well as the immune quiescence of the central nervous system (Alvarez et al. 2011). Microglia and oligodendrocytes were negative for $\mathrm{SHH}$, but Olig2 ${ }^{+}$ cells were found in close proximity to $\mathrm{S} H H$-expressing cells, which correlates well with our previous in vitro study showing that SHH promotes the generation and maintenance of forebrain Olig2 progenitors (Ortega et al. 2013).

Our finding of GLII in the fetal cortical VZ and CP suggests active SHH signaling in the developing human cortex. This result is in line with our previous demonstration of functional SHH signaling in cortical RGCs in vitro, as indicated by the increased levels of GLII and PTCHI after SHH treatment (Radonjic et al. 2016). In the present study, we provided evidence of PTCH1 (protein) as well as BOC, $G A S 1$, and $C D O N$ expression in the human RGCs of the cortical VZ, which suggest an autocrine function for SHH in these progenitors. The role of these receptors has not been studied in cortical development, but they are known as positive modulators of Shh signaling in mice, in both cell proliferation in the cerebellum (Liu et al. 2001; Izzi et al. 2011) and cell-fate specification in neural tube progenitors (Allen et al. 2007; Martinelli and Fan 2007). A recent study has shown that Boc, Cdon, and Gas 1 are necessary components of the Shh receptor complex and essential in Shh signal transduction in vertebrates (Izzi et al. 2011). Their strong expression in the human cortical VZ in association with the low-level expression of $\mathrm{SHH}$ and $\mathrm{PTCH} \mathrm{l}$ during early stages $(10 \mathrm{gw})$ suggests that they could act as enhancers of SHH signaling. Impaired function of $B O C, C D O N$, and GASI appears to underlie holoprosencephaly, both in humans (Clement et al. 2007; Ribeiro et al. 2010; Pineda-Alvarez et al. 2012; Bae et al. 2011) and in mice (Seppala et al. 2007; Zhang et al. 2006; McLellan et al. 2008). Interestingly, we found that $B O C$ is strongly expressed in the human, but not in the mouse cortical VZ (Fig. S6, brainatlas.org), suggesting a species-specific difference. Indeed, comparative epigenetic profiling of human, monkey, and mouse brain tissue identified epigenetic gains (promoters and enhancers with gained activity) in genes involved in human corticogenesis, including BOC, SHH, NKX2.1, PTCH1, and GLI3 (Reilly et al. 2015).

Recent studies have suggested that the transcriptional programs associated with interneuron development in human are very similar in the GE and cortical VZ (Miller et al. 2014), which points to a role for SHH in interneuron fate specification, in addition to cell proliferation, in the cortical VZ. Indeed, our previous in vitro results show that $\mathrm{SHH}$ affects the commitment of some cortical RGCs to interneuronal fate (Radonjic et al. 2016). This points to the need for a better understanding of the origin and development of human cortical interneurons (Radonjic et al. 2014; Alzu'bi et al. 2017; Clowry et al. 2010). Such studies are likely to provide important insights into the pathogenesis of human neuropsychiatric disorders such as schizophrenia, in which dysfunction of GABAergic interneurons has been implicated (Benes and Berretta 2001; Guidotti et al. 2005; Lewis et al. 2005; Selemon and Zecevic 2015).

In conclusion, the present study fills the gap in our knowledge about the presence of SHH in the developing human cortex which may enhance our understanding of human corticogenesis and the pathologies associated with defective SHH signaling.

Acknowledgements This work was supported by NIH Grants 2R01NSO41489 and Subcontract 5R01DA023999-07(NZ). Human fetal tissue was procured from Advanced Bioscience Resources (ABR, Alameda, CA), and the Joint Medical Research Council/Welcome Trust (Grant No. 099175/Z/12/Z Human Developmental Biology Resource http://hdbr.org), Newcastle upon Tyne, England. We are grateful to Dr Suzie Scales (Genetech) for the Shh antibody, Dr Cliff Tabin (Harvard) for the $S H H$ plasmid and Dr Bill Andrews (UCL) for critical reading of the manuscript.

\section{Compliance with ethical standards}

Conflict of interest The authors declare that they have no conflict of interest.

Ethical approval Tissue was obtained from the Human Fetal Tissue Repository at the Albert Einstein College of Medicine (Bronx), Advanced Bioscience Resources (Alameda, CA), StemEx (Diamond Springs, CA, USA) and the joint MRC/Wellcome Trust-funded Human Developmental Biology Resource (http://www.hdbr.org) after legal abortions with informed maternal written consent and approval from the Ethics Committees of the participating institutions. All human material was handled with special care and in accordance with the ethical standards set by the Ethics Committee of the University of Connecticut and the 1964 Helsinki Declaration and its later amendments or comparable ethical standards. This work was funded by NIH Grants 2R01NSO41489 and Subcontract 5R01DA023999-07(NZ).

Open Access This article is distributed under the terms of the Creative Commons Attribution 4.0 International License (http://creativeco mmons.org/licenses/by/4.0/), which permits unrestricted use, distribution, and reproduction in any medium, provided you give appropriate credit to the original author(s) and the source, provide a link to the Creative Commons license, and indicate if changes were made.

\section{References}

Allen BL, Tenzen T, McMahon AP (2007) The Hedgehog-binding proteins Gas 1 and Cdo cooperate to positively regulate Shh signaling during mouse development. Genes Dev 21(10):1244-1257. https ://doi.org/10.1101/gad.1543607 
Alvarez JI, Dodelet-Devillers A, Kebir H, Ifergan I, Fabre PJ, Terouz S, Sabbagh M, Wosik K, Bourbonniere L, Bernard M, van Horssen J, de Vries HE, Charron F, Prat A (2011) The Hedgehog pathway promotes blood-brain barrier integrity and CNS immune quiescence. Science 334(6063):1727-1731. https://doi.org/10.1126/ science. 1206936

Alzu'bi A, Lindsay S, Kerwin J, Looi SJ, Khalil F, Clowry GJ (2017) Distinct cortical and sub-cortical neurogenic domains for GABAergic interneuron precursor transcription factors NKX2.1, OLIG2 and COUP-TFII in early fetal human telencephalon. Brain struct funct 222(5):2309-2328. https://doi.org/10.1007/s0042 9-016-1343-5

Bae GU, Domene S, Roessler E, Schachter K, Kang JS, Muenke M, Krauss RS (2011) Mutations in CDON, encoding a hedgehog receptor, result in holoprosencephaly and defective interactions with other hedgehog receptors. Am J Hum Genet 89(2):231240. https://doi.org/10.1016/j.ajhg.2011.07.001

Bai CB, Stephen D, Joyner AL (2004) All mouse ventral spinal cord patterning by hedgehog is Gli dependent and involves an activator function of Gli3. Dev cell 6(1):103-115

Baudoin JP, Viou L, Launay PS, Luccardini C, Espeso Gil S, Kiyasova V, Irinopoulou T, Alvarez C, Rio JP, Boudier T, Lechaire JP, Kessaris N, Spassky N, Metin C (2012) Tangentially migrating neurons assemble a primary cilium that promotes their reorientation to the cortical plate. Neuron 76(6):1108-1122. https:// doi.org/10.1016/j.neuron.2012.10.027

Belloni E, Muenke M, Roessler E, Traverso G, Siegel-Bartelt J, Frumkin A, Mitchell HF, Donis-Keller H, Helms C, Hing AV, Heng HH, Koop B, Martindale D, Rommens JM, Tsui LC, Scherer SW (1996) Identification of sonic hedgehog as a candidate gene responsible for holoprosencephaly. Nat Genet 14(3):353-356. https://doi.org/10.1038/ng1196-353

Benes FM, Berretta S (2001) GABAergic interneurons: implications for understanding schizophrenia and bipolar disorder. Neuropsychopharmacology 25(1):1-27. https://doi.org/10.1016/s0893 $-133 \times(01) 00225-1$

Betcheva ET, Yosifova AG, Mushiroda T, Kubo M, Takahashi A, Karachanak SK, Zaharieva IT, Hadjidekova SP, Dimova II, Vazharova RV, Stoyanov DS, Milanova VK, Tolev T, Kirov G, Kamatani N, Toncheva DI, Nakamura Y (2013) Whole-genomewide association study in the Bulgarian population reveals HHAT as schizophrenia susceptibility gene. Psychiatr Genet 23(1):11-19. https://doi.org/10.1097/YPG.0b013e3283586343

Bourikas D, Pekarik V, Baeriswyl T, Grunditz A, Sadhu R, Nardo M, Stoeckli ET (2005) Sonic hedgehog guides commissural axons along the longitudinal axis of the spinal cord. Nat Neurosci 8(3):297-304. https://doi.org/10.1038/nn1396

Charron F, Stein E, Jeong J, McMahon AP, Tessier-Lavigne M (2003) The morphogen sonic hedgehog is an axonal chemoattractant that collaborates with netrin- 1 in midline axon guidance. Cell 113(1):11-23

Chiang C, Litingtung Y, Lee E, Young KE, Corden JL, Westphal H, Beachy PA (1996) Cyclopia and defective axial patterning in mice lacking sonic hedgehog gene function. Nature 383(6599):407-413. https://doi.org/10.1038/383407a0

Clement V, Sanchez P, de Tribolet N, Radovanovic I, Ruiz i Altaba A (2007) HEDGEHOG-GLI1 signaling regulates human glioma growth, cancer stem cell self-renewal, and tumorigenicity. Curr Biol 17(2):165-172. https://doi.org/10.1016/j.cub.2006.11.033

Clowry G, Molnar Z, Rakic P (2010) Renewed focus on the developing human neocortex. J Anat 217(4):276-288. https://doi.org/10.111 1/j.1469-7580.2010.01281.x

Currier DG, Polk RC, Reeves RH (2012) A sonic hedgehog (Shh) response deficit in trisomic cells may be a common denominator for multiple features of Down syndrome. Prog Brain
Res 197:223-236. https://doi.org/10.1016/b978-0-444-54299 $-1.00011-\mathrm{x}$

Dahmane N, Sanchez P, Gitton Y, Palma V, Sun T, Beyna M, Weiner H, Ruiz i Altaba A (2001) The sonic hedgehog-Gli pathway regulates dorsal brain growth and tumorigenesis. Development 128(24):5201-5212

Dave RK, Ellis T, Toumpas MC, Robson JP, Julian E, Adolphe C, Bartlett PF, Cooper HM, Reynolds BA, Wainwright BJ (2011) Sonic hedgehog and notch signaling can cooperate to regulate neurogenic divisions of neocortical progenitors. PLoS One 6(2):e14680. https://doi.org/10.1371/journal.pone.0014680

Echelard Y, Epstein DJ, St-Jacques B, Shen L, Mohler J, McMahon JA, McMahon AP (1993) Sonic hedgehog, a member of a family of putative signaling molecules, is implicated in the regulation of CNS polarity. Cell 75(7):1417-1430

Ericson J, Muhr J, Placzek M, Lints T, Jessell TM, Edlund T (1995) Sonic hedgehog induces the differentiation of ventral forebrain neurons: a common signal for ventral patterning within the neural tube. Cell 81(5):747-756

Eroglu C, Barres BA (2010) Regulation of synaptic connectivity by glia. Nature 468(7321):223-231. https://doi.org/10.1038/natur e09612

Farmer WT, Abrahamsson T, Chierzi S, Lui C, Zaelzer C, Jones EV, Bally BP, Chen GG, Theroux JF, Peng J, Bourque CW, Charron F, Ernst C, Sjostrom PJ, Murai KK (2016) Neurons diversify astrocytes in the adult brain through sonic hedgehog signaling. Science 351(6275):849-854. https://doi.org/10.1126/science.aab3103

Fuccillo M, Rallu M, McMahon AP, Fishell G (2004) Temporal requirement for hedgehog signaling in ventral telencephalic patterning. Development 131(20):5031-5040. https://doi. org/10.1242/dev.01349

Fuccillo M, Joyner AL, Fishell G (2006) Morphogen to mitogen: the multiple roles of hedgehog signalling in vertebrate neural development. Nat Rev Neurosci 7(10):772-783. https://doi.org/10.1038/ nrn1990

Geschwind DH, Rakic P (2013) Cortical evolution: judge the brain by its cover. Neuron 80(3):633-647. https://doi.org/10.1016/j.neuro n.2013.10.045

Guidotti A, Auta J, Davis JM, Dong E, Grayson DR, Veldic M, Zhang X, Costa E (2005) GABAergic dysfunction in schizophrenia: new treatment strategies on the horizon. Psychopharmacology 180(2):191-205. https://doi.org/10.1007/s00213-005-2212-8

Hajihosseini M, Tham TN, Dubois-Dalcq M (1996) Origin of oligodendrocytes within the human spinal cord. J Neurosci 16(24):7981-7994

Harwell CC, Parker PR, Gee SM, Okada A, McConnell SK, Kreitzer AC, Kriegstein AR (2012) Sonic hedgehog expression in corticofugal projection neurons directs cortical microcircuit formation. Neuron 73(6):1116-1126. https://doi.org/10.1016/j.neuro n.2012.02.009

Heussler HS, Suri M, Young ID, Muenke M (2002) Extreme variability of expression of a sonic hedgehog mutation: attention difficulties and holoprosencephaly. Arch Dis Child 86(4):293-296

Ingham PW, McMahon AP (2001) Hedgehog signaling in animal development: paradigms and principles. Genes Dev 15(23):3059 3087. https://doi.org/10.1101/gad.938601

Izzi L, Levesque M, Morin S, Laniel D, Wilkes BC, Mille F, Krauss RS, McMahon AP, Allen BL, Charron F (2011) Boc and Gas1 each form distinct Shh receptor complexes with Ptch1 and are required for Shh-mediated cell proliferation. Dev Cell 20(6):788801. https://doi.org/10.1016/j.devcel.2011.04.017

Komada M (2012) Sonic hedgehog signaling coordinates the proliferation and differentiation of neural stem/progenitor cells by regulating cell cycle kinetics during development of the neocortex. Congenit Anom (Kyoto) 52(2):72-77. https://doi.org/10.111 1/j.1741-4520.2012.00368.x 
Komada M, Saitsu H, Kinboshi M, Miura T, Shiota K, Ishibashi M (2008) Hedgehog signaling is involved in development of the neocortex. Development 135(16):2717-2727. https://doi.org/10.1242/ dev.015891

Lewis DA, Hashimoto T, Volk DW (2005) Cortical inhibitory neurons and schizophrenia. Nat Rev Neurosci 6(4):312-324. https://doi. org/10.1038/nrn1648

Liu Y, May NR, Fan CM (2001) Growth arrest specific gene 1 is a positive growth regulator for the cerebellum. Dev Biol 236(1):30-45. https://doi.org/10.1006/dbio.2000.0146

Machold R, Hayashi S, Rutlin M, Muzumdar MD, Nery S, Corbin JG, Gritli-Linde A, Dellovade T, Porter JA, Rubin LL, Dudek H, McMahon AP, Fishell G (2003) Sonic hedgehog Is required for progenitor cell maintenance in telencephalic stem cell niches. Neuron 39(6):937-950. https://doi.org/10.1016/S0896 $-6273(03) 00561-0$

Malik S, Vinukonda G, Vose LR, Diamond D, Bhimavarapu BB, Hu F, Zia MT, Hevner R, Zecevic N, Ballabh P (2013) Neurogenesis continues in the third trimester of pregnancy and is suppressed by premature birth. J Neurosci 33(2):411-423. https://doi.org/10.1523/ jneurosci.4445-12.2013

Marigo V, Roberts DJ, Lee SM, Tsukurov O, Levi T, Gastier JM, Epstein DJ, Gilbert DJ, Copeland NG, Seidman CE et al (1995) Cloning, expression, and chromosomal location of SHH and IHH: two human homologues of the Drosophila segment polarity gene hedgehog. Genomics 28(1):44-51

Maroof AM, Keros S, Tyson JA, Ying SW, Ganat YM, Merkle FT, Liu B, Goulburn A, Stanley EG, Elefanty AG, Widmer HR, Eggan K, Goldstein PA, Anderson SA, Studer L (2013) Directed differentiation and functional maturation of cortical interneurons from human embryonic stem cells. Cell Stem Cell 12(5):559-572. https://doi. org/10.1016/j.stem.2013.04.008

Martinelli DC, Fan CM (2007) Gas1 extends the range of Hedgehog action by facilitating its signaling. Genes Dev 21(10):1231-1243. https://doi.org/10.1101/gad.1546307

McLellan JS, Zheng X, Hauk G, Ghirlando R, Beachy PA, Leahy DJ (2008) The mode of Hedgehog binding to Ihog homologues is not conserved across different phyla. Nature 455(7215):979-983. https ://doi.org/10.1038/nature07358

Miller JA, Ding SL, Sunkin SM, Smith KA, Ng L, Szafer A, Ebbert A, Riley ZL, Royall JJ, Aiona K, Arnold JM, Bennet C, Bertagnolli D, Brouner K, Butler S, Caldejon S, Carey A, Cuhaciyan C, Dalley RA, Dee N, Dolbeare TA, Facer BA, Feng D, Fliss TP, Gee G, Goldy J, Gourley L, Gregor BW, Gu G, Howard RE, Jochim JM, Kuan CL, Lau C, Lee CK, Lee F, Lemon TA, Lesnar P, McMurray B, Mastan N, Mosqueda N, Naluai-Cecchini T, Ngo NK, Nyhus J, Oldre A, Olson E, Parente J, Parker PD, Parry SE, Stevens A, Pletikos M, Reding M, Roll K, Sandman D, Sarreal M, Shapouri S, Shapovalova NV, Shen EH, Sjoquist N, Slaughterbeck CR, Smith M, Sodt AJ, Williams D, Zollei L, Fischl B, Gerstein MB, Geschwind DH, Glass IA, Hawrylycz MJ, Hevner RF, Huang H, Jones AR, Knowles JA, Levitt P, Phillips JW, Sestan N, Wohnoutka P, Dang C, Bernard A, Hohmann JG, Lein ES (2014) Transcriptional landscape of the prenatal human brain. Nature 508(7495):199-206. https://doi. org/10.1038/nature 13185

Nanni L, Ming JE, Bocian M, Steinhaus K, Bianchi DW, Die-Smulders C, Giannotti A, Imaizumi K, Jones KL, Campo MD, Martin RA, Meinecke P, Pierpont ME, Robin NH, Young ID, Roessler E, Muenke M (1999) The mutational spectrum of the sonic hedgehog gene in holoprosencephaly: SHH mutations cause a significant proportion of autosomal dominant holoprosencephaly. Hum Mol Genet 8(13):2479-2488

Odent S, Atti-Bitach T, Blayau M, Mathieu M, Aug J, Delezo de AL, Gall JY, Le Marec B, Munnich A, David V, Vekemans M (1999) Expression of the sonic hedgehog $(\mathrm{SHH})$ gene during early human development and phenotypic expression of new mutations causing holoprosencephaly. Hum Mol Genet 8(9):1683-1689

Okada A, Charron F, Morin S, Shin DS, Wong K, Fabre PJ, Tessier-Lavigne M, McConnell SK (2006) Boc is a receptor for sonic hedgehog in the guidance of commissural axons. Nature 444(7117):369-373. https://doi.org/10.1038/nature05246

Ortega JA, Radonjic NV, Zecevic N (2013) Sonic hedgehog promotes generation and maintenance of human forebrain Olig2 progenitors. Front Cell Neurosci 7:254. https://doi.org/10.3389/fncel.2013.00254

Pineda-Alvarez DE, Roessler E, Hu P, Srivastava K, Solomon BD, Siple CE, Fan CM, Muenke M (2012) Missense substitutions in the GAS1 protein present in holoprosencephaly patients reduce the affinity for its ligand, SHH. Hum Genet 131(2):301-310. https://doi. org/10.1007/s00439-011-1078-6

Pollen AA, Nowakowski Tomasz J, Chen J, Retallack H, Sandoval-Espinosa C, Nicholas Cory R, Shuga J, Liu Siyuan J, Oldham Michael C, Diaz A, Lim Daniel A, Leyrat Anne A, West Jay A, Kriegstein Arnold R (2015) Molecular Identity of human outer radial glia during cortical development. Cell 163(1):55-67. https://doi. org/10.1016/j.cell.2015.09.004

Radonjic NV, Ayoub AE, Memi F, Yu X, Maroof A, Jakovcevski I, Anderson SA, Rakic P, Zecevic N (2014) Diversity of cortical interneurons in primates: the role of the dorsal proliferative niche. Cell Rep 9(6):2139-2151. https://doi.org/10.1016/j.celrep.2014.11.026

Radonjic NV, Memi F, Ortega JA, Glidden N, Zhan H, Zecevic N (2016) The role of sonic hedgehog in the specification of human cortical progenitors in vitro. Cereb cortex 26(1):131-143. https://doi. org/10.1093/cercor/bhu183

Reilly SK, Yin J, Ayoub AE, Emera D, Leng J, Cotney J, Sarro R, Rakic P, Noonan JP (2015) Evolutionary genomics. Evolutionary changes in promoter and enhancer activity during human corticogenesis. Science 347(6226):1155-1159. https://doi.org/10.1126/science.12609 43

Ribeiro LA, Quiezi RG, Nascimento A, Bertolacini CP, Richieri-Costa A (2010) Holoprosencephaly and holoprosencephaly-like phenotype and GAS1 DNA sequence changes: report of four Brazilian patients. Am J Med Genet A 152a(7):1688-1694. https://doi.org/10.1002/ ajmg.a.33466

Santiago G, Abramides DV, De-Vitto LP, Ribeiro LA, Meira SG Jr, Richieri-Costa A (2006) Language skills and neuropsychological performance in patients with SHH mutations and a holoprosencephaly-like phenotype. Am J Med Genet A 140(19):2085-2090. https:// doi.org/10.1002/ajmg.a.31311

Selemon LD, Zecevic N (2015) Schizophrenia: a tale of two critical periods for prefrontal cortical development. Transl Psychiatry 5:e623. https://doi.org/10.1038/tp.2015.115

Seppala M, Depew MJ, Martinelli DC, Fan CM, Sharpe PT, Cobourne MT (2007) Gas1 is a modifier for holoprosencephaly and genetically interacts with sonic hedgehog. J Clin Invest 117(6):1575-1584. https ://doi.org/10.1172/jci32032

Silbereis JC, Pochareddy S, Zhu Y, Li M, Sestan N (2016) The cellular and molecular landscapes of the developing human central nervous system. Neuron 89(2):248-268. https://doi.org/10.1016/j.neuro n.2015.12.008

Tekki-Kessaris N, Woodruff R, Hall AC, Gaffield W, Kimura S, Stiles CD, Rowitch DH, Richardson WD (2001) Hedgehog-dependent oligodendrocyte lineage specification in the telencephalon. Development 128(13):2545-2554

Tenzen T, Allen BL, Cole F, Kang JS, Krauss RS, McMahon AP (2006) The cell surface membrane proteins Cdo and Boc are components and targets of the Hedgehog signaling pathway and feedback network in mice. Dev Cell 10(5):647-656. https://doi.org/10.1016/j. devcel.2006.04.004

Tyson JA, Goldberg EM, Maroof AM, Xu Q, Petros TJ, Anderson SA (2015) Duration of culture and sonic hedgehog signaling differentially specify PV versus SST cortical interneuron fates from 
embryonic stem cells. Development 142(7):1267-1278. https://doi. org/10.1242/dev.111526

Wang L, Hou S, Han YG (2016a) Hedgehog signaling promotes basal progenitor expansion and the growth and folding of the neocortex. Nat Neurosci 19(7):888-896https://doi.org/10.1038/nn.4307

Wang Y, Wu Q, Yang P, Wang C, Liu J, Ding W, Liu W, Bai Y, Yang Y, Wang H, Gao S, Wang X (2016b) LSD1 co-repressor Rcor2 orchestrates neurogenesis in the developing mouse brain. Nat Commun 7:10481. https://doi.org/10.1038/ncomms10481

Xu Q, Wonders CP, Anderson SA (2005) Sonic hedgehog maintains the identity of cortical interneuron progenitors in the ventral telencephalon. Development 132(22):4987-4998. https:// doi.org/10.1242/dev.02090

Yam PT, Langlois SD, Morin S, Charron F (2009) Sonic hedgehog guides axons through a noncanonical, Src-family-kinase-dependent signaling pathway. Neuron 62(3):349-362. https://doi.org/10.1016/j.neuro n.2009.03.022

Zhang W, Kang JS, Cole F, Yi MJ, Krauss RS (2006) Cdo functions at multiple points in the sonic hedgehog pathway, and Cdo-deficient mice accurately model human holoprosencephaly. Dev cell 10(5):657-665. https://doi.org/10.1016/j.devcel.2006.04.005 